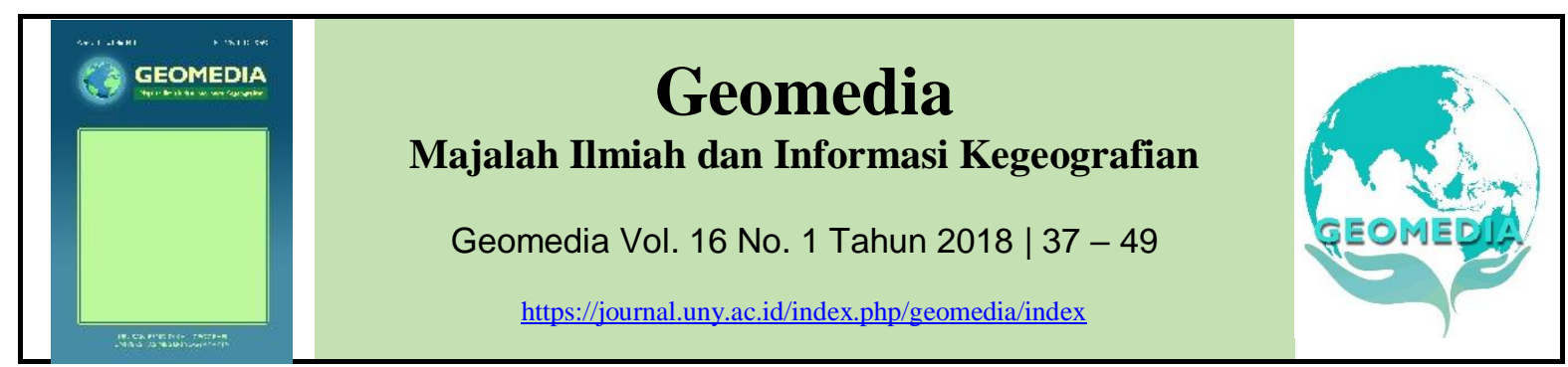

\title{
Pengembangan ekowisata berbasis evolusi bentanglahan Danau Purba Borobudur kala pleistosen akhir di kawasan Borobudur
}

\author{
Irma Yunanda ${ }^{a} 1^{\star}$, Norma Yuni Praptiwi ${ }^{a, 2}$, Andika Eka Damayanti ${ }^{\text {b, } 3}$ Nurhadi $^{\text {a.4 }}$ \\ a Jurusan Pendidikan Geografi, b Jurusan IImu Sejarah, Fakultas IImu Sosial Universitas Negeri Yogyakarta \\ 1 irma.yunanda2016@student.uny.ac.id *; ${ }^{2}$ norma.yuni2016@student.uny.ac.id; 3andika.eka2016@student.uny.ac.id \\ , ${ }^{4}$ nurhadi_fise@uny.ac.id \\ *korespondensi penulis
}

\section{Informasi artikel}

\section{Kata kunci:}

Kata kunci 1 Ekowisata

Kata kunci 2 Borobudur

Kata kunci 3 Bentanglahan

Kata kunci 4 Danau Purba

\begin{abstract}
A B S T R A K
Penelitian ini dilakukan di kawasan Borobudur tepatnya di daerah bentanglahan danau Borobudur Purba Kala Peistosen dengan tujuan: (1) mengidentifikasi lokasi-lokasi yang dapat dikembangkan sebagai tujuan ekowisata di kawasan Danau Borobudur Purba, (2) mengembangkan desain ekowisata berbasis evolusi bentanglahan di kawasan Danau Borobudur Purba. Metode yang digunakan adalah deskriptif eksploratif dengan pendekatan geografi yaitu pendekatan keruangan. Populasi dalam penelitian ini adalah seluruh wilayah Danau Purba Borobudur. Sampel diambil dengan teknik sistematik sampling dengan membuat grid untuk menentukan zona penelitian. Analisis menggunakan cara deskriptif kualitatif dilandasi konsep dasar geomorfologi. Analisis ini didukung dengan analisis SWOT untuk menilai titik lokasi yang dapat di rekomendasikan untuk dijadikan sebagai objek ekowisata. Hasil penelitian: (1) Terdapat lima objek bekas Danau Purba Borobudur yang dapat dikembangkan sebagai objek ekowisata berbasis evolusi bentanglahan (2) Desain pengembangan ekowisata kawasan Danau Purba Borobudur yaitu menggunakan SWOT yang diharapkan dapat memberikan masukan dalam pengembangan wisata di wilayah ini.
\end{abstract}

\section{Keywords:}

Keyword 1 Ecotourism

Keyword 2 Borobudur

Keyword 3 Landscape

Keyword 4 Ancient Lake

\begin{abstract}
A B S T R A C T
This research is conducted in Borobudur area in the landscape of Borobudur Ancient lake Peistocene with the aims: (1) Identity of locations that can be developed as ecotourism destination in Borobudur Ancient Lake Area, (2) develop ecotourism design using spanning analysis in Borobudur Ancient Lake Area. The method used is descriptive explorative by using geography that is spatial approach. The population in this study is the entire area of Borobudur Ancient Lake. Analysis by systematic sampling technique by creating a grid to determine the research zone. The analysis used qualitative descriptive method based on the basic concept of geomorphology. This analysis is supported by a SWOT analysis to assess the recommended locations for ecotourism purposes. Result of research: (1) There are five ancient objects of Ancient Borobudur Lake Area that can be developed as ecotourism destination, based on the landscape evolution (2) Design of ecotourism development of Borobudur Ancient Lake Area, that is using SWOT, that can be a recomendation to develop ecotourism in this area.
\end{abstract}

(c) 2018 (Irma Yunanda, dkk). All Right Reserved

\section{Pendahuluan}

Pulau Jawa memiliki kondisi lingkungan fisik yang unik. Keunikan lingkungan fisik ini tidak terlepas dari kedudukan Pulau Jawa yang berada pada pertemuan lempeng tektonik besar yaitu antara Lempeng Hindia-Australia dan Asia
Tenggara (Verstappen, 2013) dengan karakteristik subduksi, sehingga membentuk jalur pegunungan dan vulkan. Di Pulau Jawa, proses endogen yang berkaitan dengan aktivitas subduksi lempeng tektonik selanjutnya berkombinasi dengan proses eksogen yang 
dicirikan oleh iklim tropis basah. Hasil interaksi yang terus menerus antara proses endogen dengan eksogen tersebut menyebabkan terjadinya evolusi bentanglahan. Selain menghasilkan fenomena alam yang unik, evolusi yang telah berlangsung sepanjang kurun waktu geologi seringkali juga menghasilkan fenomena alam yang bernilai ilmiah tinggi. Tingginya keunikan dan nilai ilmiah ditambah keindahan panorama alam dari segi estetika perlu dikelola dengan baik salah satunya dengan melakukan pengembangan ekowisata.

Kawasan Borobudur merupakan salah satu tempat di Pulau Jawa yang memiliki keunikan geologis dan geomorfologis, jika ditinjau dari aspek evolusi bentanglahan. Berdasarkan pembagian zona fisiografi Van Bemmelen (1949), kawasan Borobudur terletak di zona sentral dan depresi yang memiliki ketinggian dataran 225-240 mdpl. Kawasan Borobudur berada di dataran rendah, di sisi selatan terdapat pegunungan memanjang dengan arah timur-barat sepanjang $20 \mathrm{~km}$ yang disebut Pegunungan Menoreh. Selain itu di sekitar kawasan Borobudur juga terdapat beberapa gunungapi aktif, antara lain Gunung Merapi, Gunung Merbabu, dan Gunung Sumbing (Murwanto, 2015).

Selama ini Kawasan Borobudur masih identik dengan Candi Borobudur yang merupakan tujuan wisata internasional dan juga situs warisan budaya dunia (world heritage site) milik UNESCO. Namun demikian, di kawasan ini sebenarnya juga terdapat potensi lain yang dapat dikembangkan sebagai tujuan wisata, khususnya wisata edukasi. Potensi yang dimaksud adalah keunikan geologis dan geomorfologis yang berada di wilayah bekas Danau Purba Borobudur.

Danau Borobudur Purba merupakan bentangalam danau yang terbentuk pada Kala Pleistosen Akhir. Keberadaan danau tersebut dikenali dari adanya singkapan endapan danau berupa lempung hitam yang terdapat di wilayah sekitar Candi Borobudur. Material penutup endapan danau purba berupa material vulkanik dan sedimentasi dari Pegunungan Menoreh. Dalam kurun waktu yang lama, sebagian besar bentangalam danau tersebut mengalami pendangkalan dan berubah menjadi dataran aluvial dan bekas rawa. Faktor penyebab pendangkalannya dapat diamati dari material penutup endapan yang terdapat pada bekas danau yaitu material yang berasal dari hasil aktivitas vulkanik, tektonik, gerakan massa tanah dan batuan, serta aktivitas manusia. Selama kurun waktu tersebut Danau Borobudur lenyap perlahan-lahan namun jejaknya masih bisa dikenali pada saat sekarang (Murwanto, 2015, Murwanto dan Purwoaminta, 2015, Murwanto dkk, 2014).

Keberadaan Danau Purba Borobudur dan evolusi bentanglahan yang terjadi merupakan aspek yang menarik untuk diangkat sebagai atraksi wisata, melengkapi dan mendukung keberadaan Candi Borobudur yang telah berkembang sebagai tujuan wisata utama di kawasan ini. Murwanto (2015) telah mengidentifikasi dan merekomendasikan beberapa objek yang potensial untuk dikembangkan sebagai tujuan ekowisata. Beberapa objek tersebut antara lain bekas rawa antara Desa Bumisegoro dan Desa Sabrangrawa, keberadaan struktur sesar dan air asin pada Sungai Sileng Dusun Kaliduren, struktur sesar Sungai Progo di bawah jembatan Sigug, singkapan breksi Old Andesite Formation $(O A F)$, serta endapan kipas muara/konglomerat Sungai Elo dan Sungai Progo dengan endapan kipas delta Sungai Pabelan lama. Selain objek fisik tersebut juga terdapat keunikan sosial budaya berupa toponim nama Dusun Bumisegoro, Dusun Sabrangrowo, Dusun Teluk, dan Desa Tanjung. Toponim ini memiliki keunikan karena berkaitan dengan lingkungan perairan yang pada saat ini tidak lagi dijumpai di wilayah Borobudur.

Potensi wisata yang berupa keunikan aspek fisik dan sosial budaya sebagai hasil evolusi bentanglahan perlu dikelola dengan baik. Salah satu bentuk pengelolaan yang diusulkan adalah melalui pengembangan ekowisata. Nuraini dan Pramono (2013) menjelaskan bahwa ekowisata berbeda dengan kegiatan wisata secara umum. Dalam ekowisata terdapat konsep tersendiri yaitu wisatawan yang menikmati keindahan alam juga diajak untuk memahami dan menghayati nilai-nilai serta ditanamkan pemahaman dan kepedulian terhadap pelestarian lingkungan. Hal ini mengacu kepada aspek ekowisata sebagaimana dijelaskan oleh Baiquni (2001) yang terdiri dari aspek scientific, aestethic, dan philosophical. Pengembangan ekowisata di Wilayah Borobudur memiliki peluang yang besar karena didukung oleh keberadaan Candi Borobudur yang telah eksis 
dan dikenal dunia sebagai destinasi wisata internasional. Candi Borobudur pada tahun 2015 dikunjungi oleh 3,5 juta wisatawan sedangkan tahun 2016 jumlah wisatawan meningkat menjadi 3,7 juta (Priherdityo, 2017). Faktor Candi Borobudur ini memberikan peluang besar bagi keberhasilan ekowisata dan diharapkan dapat menjadi pendukung pengembangan ekowisata di wilayah ini.

Sementara itu disisi lain, Candi Borobudur sebagai tujuan wisata internasional yang banyak diminati ternyata belum sepenuhnya mendongkrak kesejahteraan masyarakat sekitar. Hal ini antara lain disebabkan karena masih rendahnya kontribusi pendapatan dari pengelola kepada desa-desa di sekitarnya (Parwito, 2013). Melalui pengembangan ekowisata diharapkan terdapat alternatif lain yang dapat berperan dalam mendorong pertumbuhan perekonomian Kawasan Borobudur. Pada saat ini ekowisata juga telah dikembangkan di Desa Wisata Candirejo yang terdapat di Kecamatan Borobudur. Keberadaan ekowisata yang telah ada dan menonjolkan aspek budaya (Ida, 2016) diharapkan juga akan semakin berkembang baik apabila didukung dengan penambahan objek khususnya aspek fisik yang berkaitan dengan sejarah geologis dan geomorfologis masa lampau dari wilayah ini. Melalui ekowisata, para wisatawan yang berkunjung selain dapat melihat keindahan dari tempat wisata juga dapat mempelajari nilai-nilai ilmiahnya dan menghayati nilai-nilai dari kearifan lokal masyarakat setempat.

\section{Metode}

Penelitian ini menggunakan metode penelitian deskriptif. Metode deskriptif dimaksudkan untuk mengungkapkan suatu masalah atau keadaan berdasarkan fakta-fakta yang ada di lapangan. Terkait dengan populasinya penelitian ini menggunakan sampling, terkait dengan karaktersitik objeknya penelitian ini menggunakan metode survei, dan terkait dengan analisisnya penelitian ini menggunakan analisis kuantitatif. Pendekatan yang digunakan dalam penelitian ini adalah pendekatan geografi yaitu pendekatan keruangan serta menekankan tema geografi yaitu lokasi (location) dan tempat (place) dalam pembahasannya.

Populasi dalam penelitian ini adalah seluruh wilayah Danau Purba di Kawasan
Borobudur pada Kala Pleistosen mengacu kepada pembatasan wilayah yang dibuat oleh Murwanto (2015). Pengambilan sampel dilakukan dengan teknik sistematik sampling yaitu dengan membuat grid untuk menentukan zona-zona survei di daerah penelitian. Pada setiap zona survei dilakukan pengamatan untuk menemukan kemungkinan keterdapatan objek yang dapat dikembangkan sebagai atraksi ekowisata.

Pengumpulan data dilakukan dengan observasi, wawancara dan studi pustaka. Analisis dalam penelitian ini menggunakan analisis deskriptif dan analisis SWOT. Untuk menjawab tujuan penelitian pertama digunakan analisis deskriptif kualitatif. Berbagai data hasil observasi dan dokumentasi yang telah dikumpulkan kemudian dianalisis dengan menunjukkan titik lokasi mana saja yang dapat direkomendasikan untuk pengembangan ekowisata. Selanjutnya untuk menjawab tujuan yang kedua digunakan analisis SWOT. Dari analisis SWOT ini, lokasi yang layak dijadikan sebagai lokasi ekowisata ditentukan kekuatan, kelemahan, peluang, dan ancamannya apabila dikembangkan sebagai tujuan ekowisata. Berdasarkan identifikasi aspek kekuatan, kelemahan, peluang, dan ancaman tersebut dapat dibuat desain ekowisata untuk masingmasing lokasi. Metode anaisis ini pernah digunakan oleh Nuraini dan Pramono (2013) dalam perencanaan pengembangan ekowisata di Kawasan Karst Ponjong, Gunung Kidul, serta oleh Masruri (2017) di Wilayah Escarpment Baturagung, Yogyakarta.

\section{Hasil dan pembahasan Daerah Penelitian}

Daerah penelitian meliputi seluruh wilayah Danau Borobudur Purba pada Kala Pleistosen Akhir (Gambar 1). Dalam kaitannya dengan tujuan untuk menyusun contoh pengembangan ekowisata di sekitar Candi Borobudur, daerah penelitian dipersempit ke dalam wilayah yang lebih spesifik yaitu pada kawasan terdekat dengan Candi Borobudur. Kawasan yang dimaksud meliputi Dusun Kaliduren, Dusun Bumisegoro, Dusun Sabrangrawa, Dusun Mbejen, Dusun Ngentak, Dusun Ngaran, yang terdapat di Kecamatan Borobudur. Secara Astronomis Kecamatan Borobudur yang menjadi wilayah inti dari penelitian ini terletak diantara $110^{\circ} 01^{\prime} 51^{\prime \prime}$ BT dan 7³5'99" LS. Kecamatan Borobudur mempunyai luas wilayah 54,55 km² 
dengan jumlah penduduk pada tahun 2016 sebanyak 58,140 jiwa.

Danau Borobudur Purba merupakan sebuah basin berupa danau yang telah mengalami berbagai proses geomorfik sehingga mengalami pendangkalan dan pada saat ini berubah menjadi daratan. Pada wilayah dataran inilah terdapat Candi Borobudur dan candi-candi lain di sekitarnya. Perubahan bentuklahan ini dipengaruhi oleh aktivitas vulkanik, tektonik, gerakan tanah, serta aktivitas manusia. Aktivitas vulkanik dan sedimen dari pegunungan Menoreh merupakan faktor utama yang pendangkalan danau tersebut. Aktivitas vulkanik berasal dari aktivitas Gunung Sumbing yang berada di sisi sebelah barat dan material dari Gunung Tidar. Struktur geologi di daerah ini menunjukan banyak struktur sesar. Aktivitas sesar ini juga berperan dalam proses pendangkalan melalui pengangkatan dan pergeseran. Proses pengangkatan berdampak pada pembelokan Sungai Tangsi yang kemudian akan berpengaruh terhadap terhalangnya suplai air menuju danau sehingga menyebabkan danau mengalami pengeringan. Saat ini sebagian besar bentuklahan danau purba telah berubah menjadi daratan alluvial dan bekas rawa-rawa (Murwanto, 2015).

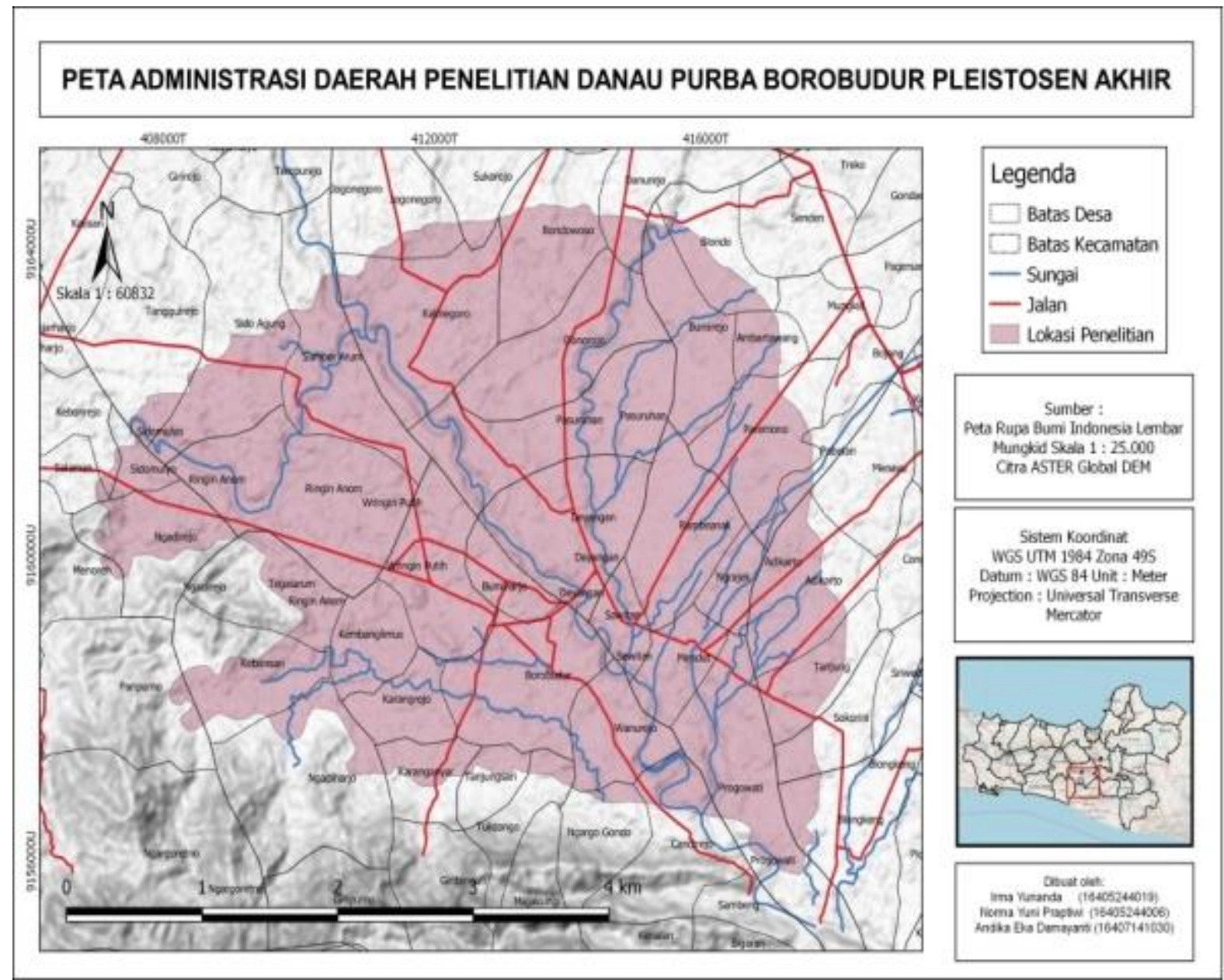

Gambar 1 Daerah penelitian Danau Purba Borobudur Kala Pleistosen Akhir

Lokasi-lokasi yang dapat dikembangkan sebagai tujuan ekowisata di kawasan Borobudur

Baiquni (2001) menjelaskan bahwa ekowisata memiliki ciri kegiatan yang berbasis keinginan untuk tahu (scientific), mengerti dan menikmati keindahan (aesthetic), serta menghayati nilai dan makna (philosophical).
Berdasarkan konsep ini peminat ekowisata memiliki ciri yang berbeda dengan wisatawan secara umum. Dalam kegiatan ekowisata, wisatawan menikmati keindahan alam tetapi juga memiliki perhatian dan penghargaan pada budaya setempat. Salah satu nilai keunggulan ekowisata adalah penerapan aspek scientific yang memberikan nilai edukasi kepada 
wisatawan. Dengan demikian, melalui ekowisata wisatawan tidak hanya menikmati keindahan alam tetapi juga mendapatkan informasi bernilai ilmiah mengenai objek tersebut. Ekowisata yang mendukung berkembangnya suatu wisata bernilai edukasi umumnya memiliki keunikan alam tersendiri. Keunikan alam terbentuk oleh proses alam berupa proses geologi dan geomorfologi yang menjadi ciri khas ekowisata tersebut.

Berdasarkan pada rekomendasi dari penelitian sebelumnya oleh Murwanto (2015), kawasan bentanglahan Danau Purba Borobudur dapat dikembangkan sebagai kawasan ekowisata. Pengembangan ekowisata ini bermanfaat untuk meningkatkan potensi pariwisata di Kawasan Borobudur. Terdapat beberapa wilayah yang direkomendasikan sebagai tujuan wisata antara lain bentangalam bekas rawa antara Dusun Bumisegoro dan Sabrangrawa, struktur sesar dan air asin pada Sungai Sileng Dusun Kaliduren, Struktur sesar Sungai Progo di bawah jembatan Sigug, mataair di sekitar Candi Pawon, singkapan breksi OAF, endapan kipas/muara konglomerat dan pertemuan antara Sungai Progo dan Elo. Persebaran objek tersebut terhadap Candi Borobudur ditunjukkan oleh Gambar 2. Adapun gambaran kondisi lapangan dari beberapa objek yang direkomendasikan untuk ekowisata ditunjukkan oleh Gambar 3.

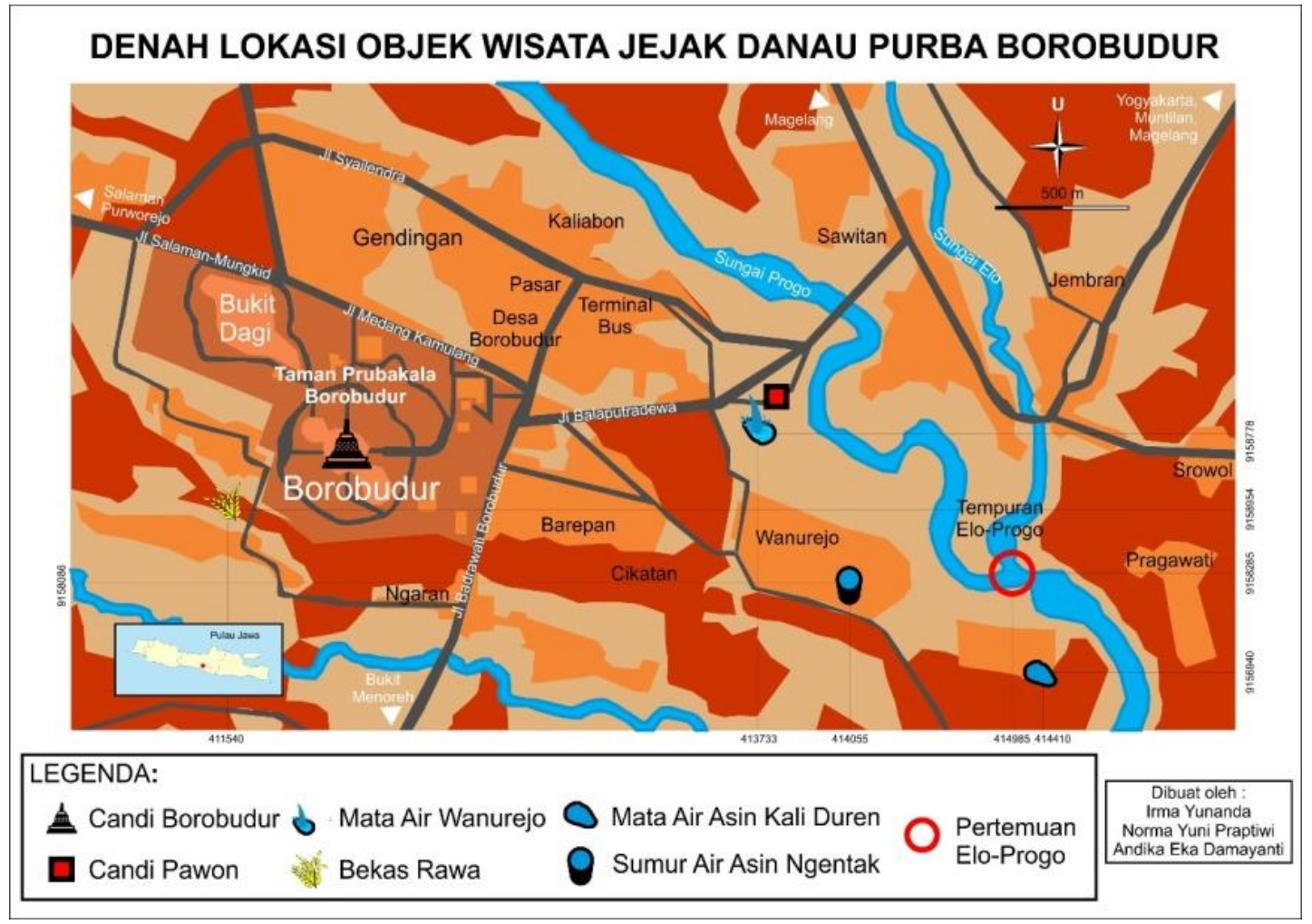

Gambar 2 Titik Lokasi Objek Ekowisata

Dusun Bumisegoro dan Sabrangrawa secara admnistratif berada di Kecamatan Borobudur Kabupaten Magelang. Dusun ini memiliki keunikan karena merupakan bekas rawa dari Danau Purba Borobudur pada Kala Pleistosen. Toponim kedua nama dusun tersebut memperkuat kemungkinan adanya lingkungan perairan pada masa lampau. Nama Dusun Bumisegoro berasal kata dari Bumi dan Segoro, Bumi dimaknai sebagai suatu daerah dalam cakupan yang luas sedangkan Segoro berarti laut, jadi makna toponim tersebut berarti suatu daerah yang dikelilingi oleh perairan yang luas, sementara nama Dusun Sabrangrawa berasal dari kata Sabrang yang berarti bersebrangan dan Rawa yang berarti suatu genangan air. Berdasarkan toponim ini dapat diketahui bahwa pada masa lampau di wilayah ini terdapat lingkungan perairan yang luas.

Mataair asin terletak di Desa Kaliduren, Kecamatan Borobudur Kabupaten Magelang, Jawa Tengah yang berada pada titik koordinat antara 414410 MT dan 9156940 MU. Keberadaan mataair asin berkaitan dengan evolusi bentanglahan pada masa lampau yang memungkinkan air asin atau air purba terjebak 
dalam perlapisan batuan di wilayah in Berdasarkan salah satu konsep dasar dalam geomorfologi yaitu the present is the key to the past kejadian alam berupa air asin yang ada sekarang ini sebenarnya merupakan hasil proses yang berkesinambungan sepanjang kurun waktu geologi. Hal ini merupakan informasi yang menarik yang perlu dipahami oleh wisatawan baik dalam konteks scientific maupun philosophical.
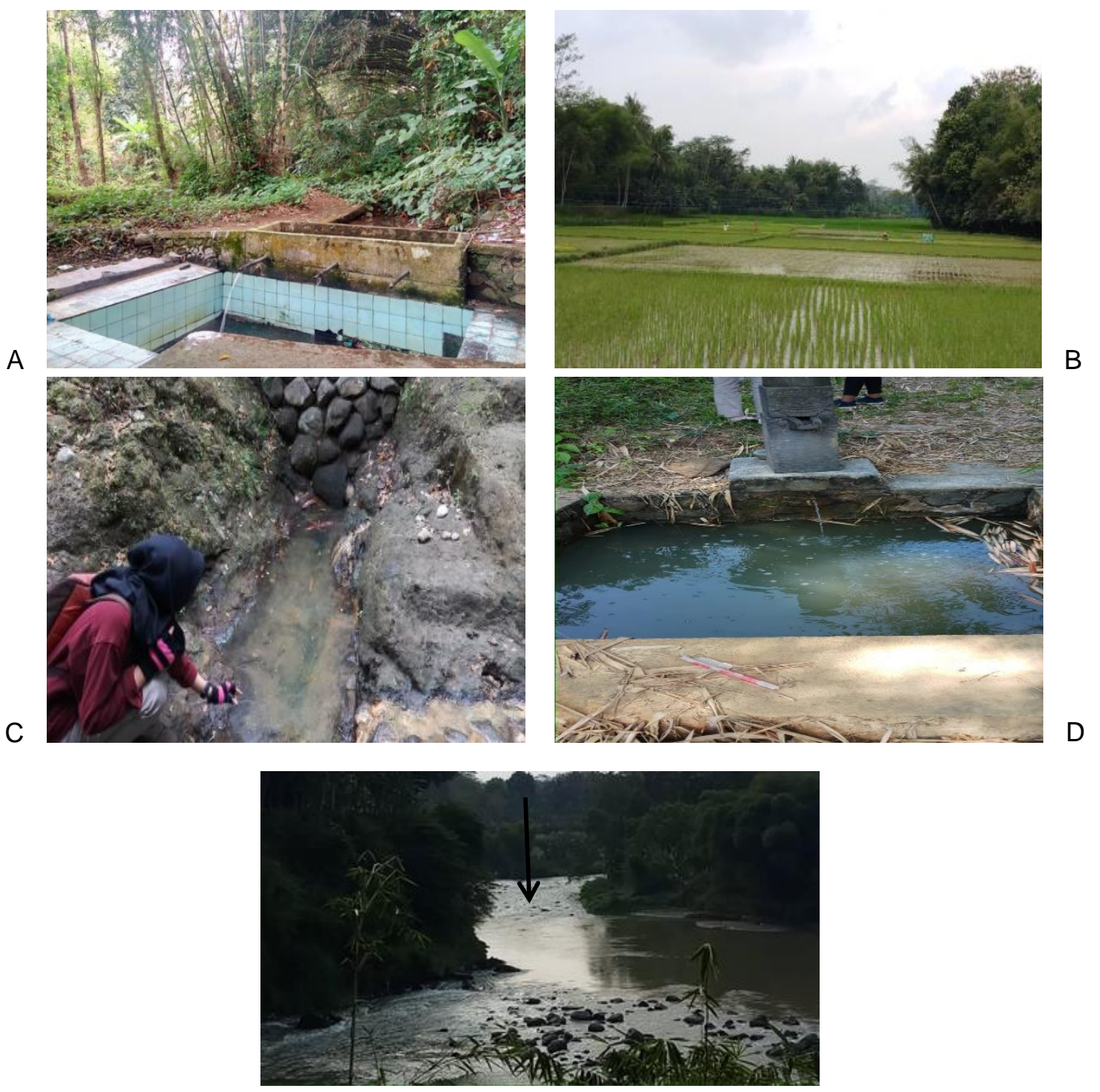

(E)

Gambar 3 Beberapa indikator evolusi bentanglahan yang memiliki potensi ekowisata: (A) Mataair di Dusun Wanurejo, (B) Bekas rawa di Dusun Sabrangrawa dan Dusun Bumisegoro, (C) Mataair Asin di Dusun Kaliduren, (D) Sumur Air Asin di Dusun Ngentak, Pertemuan Sungai Elo dan Sungai Progo di Dusun Mbejen (data lapangan 2018).

Objek menarik lainnya yang terdapat di wilayah Borobudur adalah adanya struktur sesar. Struktur sesar ini menjadi menarik karena berkaitan dengan berbagai fenomena alam antara lain pembelokan alur sungai serta pemunculan mataair panas yang berasa asin. Data pendukung struktur sesar di Dataran Borobudur adalah terdapatnya mataair panas dengan rasa asin muncul melalui kekar-kekar yang memotong satuan breksi vulkanik produk
Gunungapi Sumbing. Mataair asin juga ditemukan di sebelah barat Desa Ngasinan, pada lembah Sungai Klantangan. Struktur kekar yang mengakibatkan munculnya mataair asin diduga sebagai akibat proses sekunder dari Sesar Tangsi

Objek selanjutnya adalah pertemuan Sungai Elo dan progo ini secara administratif berada di Dusun Mbejen, Kecamatan Borobudur, dan berada di titik koordinat 414985 MT dan 
9158285 MU. Sungai Progo merupakan sungai yang berhulu di Gunung Sindoro dan melintasi Daratan Kedu. Pada saat pembentukan danau, muara sungai diperkirakan terletak di Desa Bumiaarjo. Sungai Elo merupakan sungai yang berulu di Gunung Merbabu mengalir ke daratan lakustrin dan bermuara di Dusun Bojong, pertemuan dua sungai ini juga dipengaruhi oleh pembelokan jalur sesar akibat adanya tenaga tektonik (Murwanto, 2015).

Sumur Asin terletak di Dusun Ngentak Kecamatan Borobudur Kabupaten Magelang, dengan titik koordinat 414055 MT dan 9158086 MU, sumur ini juga merupakan bekas dari peninggalan Danau Borobudur Purba yang pernah terjadi. Sumur asin ini muncul sebagai indikasi adanya aktivitas tektonik yang berperan terhadap pendangkalan danau. Air tanah di lokasi tersebut terkandung dalam batulempung hitam yang kontak dengan breksi vulkanik Formasi Andesit Tua, besarnya kandungan unsur $\mathrm{NaCl}$ menakibatkan rasa asin (Murwanto, 2015).

Beberapa mataair terdapat di Dusun Wanurejo, Kecamatan Borobudur tepatnya dibelakang Candi Pawon, dan terletak pada titik koordinat 413733 MU-9158778 MT, objek mataair ini termasuk ke dalam jenis mataair kontak. Murwanto (2015) menjelaskan jenis mataair ini dipengaruhi oleh kondisi litostratigrafi dan kondisi topografi. Kondisi litostratigrafi di daerah daratan lakustrin dan bentuklahan dataran kaki Gunung Merapi dan Sumbing batuannya tersusun oleh dua satuan batuan yang berbeda sifatnya terhadap daya serap air. Batuan tersebut merupakan lapisan batuan sedimen yang bersifat kedap air dan diatasnya tertutup oleh batuan sedimen vulkanik yang mempu meloloskan air. Selanjutnya pembentukan lembah sungai menyebabkan terpotongnya lapisan sedimen yang beda permeabilitasnya. Akibatnya muncul sumber mataair ditengah lembah sungai diatas batas kontak batuan.

\section{Desain ekowisata berbasis evolusi bentanglahan di kawasan Danau Borobudur Purba}

Keberadaan Danau Purba Borobudur dan evolusi bentanglahan yang terjadi pada masa lampau menyisahkan bukti-bukti baik secara fisik maupun sosial. Kedua bukti jejak evolusi bentanglahan tersebut dapat dikombinasikan menjadi sebuah atraksi wisata berbasis edukasi yang menarik. Atraksi wisata dapat dikemas sebagai desain tata ruang objek ekowisata. Dengan adanya pengembangan objek wisata ini diharapkan dapat meningkatkan peran masyarakat dalam pengelolaan pariwisata lokal serta peningkatan income masyarakat sekitar.

Pada bagian sebelumnya telah dibahas beberapa objek di sekitar Candi Borobudur yang dapat dikembangkan sebagai tujuan wisata. Selain berdasarkan pada rekomedasi dari penelitian sebelumnya, penelitian ini juga mengidentifikasi secara langsung objek-objek yang ada di lapangan. Selanjutnya untuk mengembangkan ekowisata pada masingmasing objek tersebut dilakukan analisis SWOT dan disusun desain ekowisata yang dapat digunakan sebagai rekomendasi bagi pengembangan ekowisata. Hasil analisis SWOT masing-masing objek dijelaskan sebagai berikut.

Lokasi pertama adalah mataair di sekitar Candi Pawon. Lokasi ini ini dapat direkomendasikan sebagai objek ekowista berbasis edukasi karena memiliki aspek scientific ditinjau dari keunikan geologis dan geomorfologis yang berkaitan dengan evolusi bentanglahan dalam proses pendalaman lembah sungai. Selain aspek scientific tersebut, mataair juga memiliki nilai spritual yang tinggi dan pada saat-saat tertentu sering digunakan sebagai tempat untuk melakukan tradisi jawa yaitu tirakatan sehingga memiliki nilai philosophical. Kedua aspek tersebut dapat menjadi kekuatan dalam penerapan ekowisata berbasis edukasi pada bekas Danau Purba Kala Pleistosen. Keberadaan Candi Pawon juga dapat menjadi daya tarik bagi wisatawan minat khusus untuk berkunjung ke objek ini. Kelemahan dari objek ini secara umum adalah belum adanya infrastruktur pendukung. Analisis SWOT untuk lokasi pertama secara rinci ditunjukkan oleh Tabel 1.

Bekas Rawa di antara Desa Bumisegoro dan Desa Sabrangrowo mempunyai potensi ekowisata karena objek wisata tersebut mengandung unsur scientific. Dari aspek fisik bekas rawa tersebut merupakan salah satu bukti yang perubahan bentanglahan dari Danau Purba Borobudur menjadi dataran aluvial. Kemudian dari aspek sosial toponim Desa Bumisegoro dan Desa Sabrangrowo juga mengindikasikan lingkungan perairan yang saat ini tidak terdapat di wilayah tersebut. Nilai scientific ini dapat menjadi daya tarik bagi wisatawan minat khusus. Kekurangan dari objek ini secara umum adalah terbatasnya lahan karena bekas rawa yang 
sudah mengalami pendangkalan saat ini berkembang sebagai area permukiman serta persawahan. Untuk itu perlu di rencanakan suatu desain tata ruang agar objek tersebut dapat lebih menarik jika dikembangkan sebagai tujuan wisata. Analisis SWOT untuk lokasi kedua ditunjukkan pada Tabel 2.

Tabel 1. Analisis SWOT beberapa Mataair di sekitar Candi Pawon

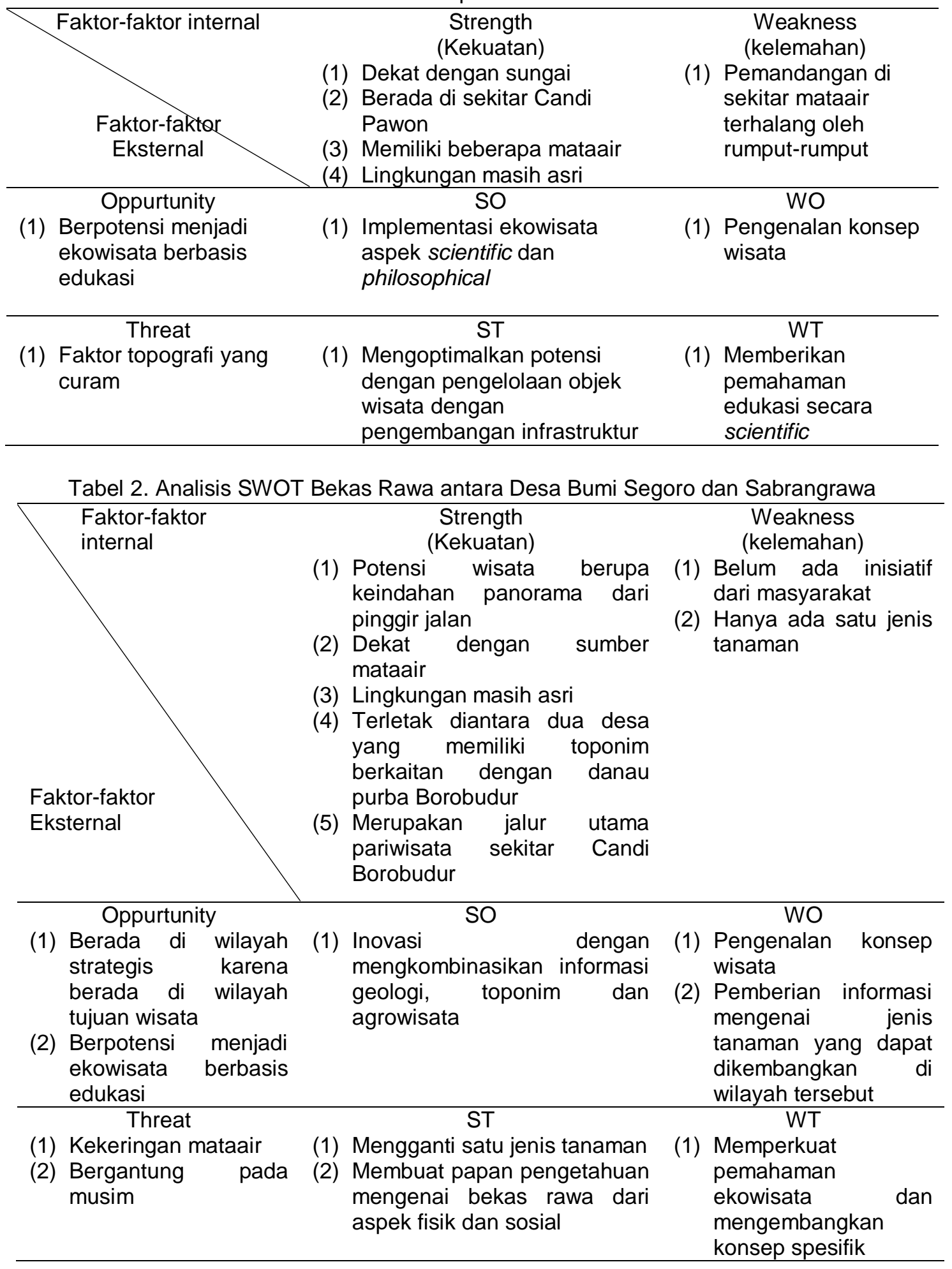


Mataair di Dusun Kaliduren ini mempunyai kekuatan terutama dari aspek scientific (Perhatikan matriks analisis swot di Tabel 3). Secara scientific wilayah ini memiliki keunikan geologi dan geomorfologinya sebagai salah satu bukit bekas Danau Purba Borobudur. Ditinjau dari kondisi lingkungannya, sebenarnya sudah ada kesadaran dari masyarakat sekitar untuk membangun kawasan wisata di tempat ini. Namun demikian pengembangan wisata yang telah dilakukan masih terbatas pada wisata aesthetic sehingga belum banyak menggarap aspek edukasi. Pengelolaan wisata yang dilakukan juga masih terbatas. Hal ini juga dipengaruhi oleh belum adanya sarana prasarana pedukung. Lokasi ini memiliki peluang yang besar untuk menjadi tujuan wisatawan minat khusus, akan tetapi masih perlu pengolahan lahan dan penataan desain tata ruang di objek ini agar dapat menjadi daya tarik untuk para wisatawan yang berkunjung.

Tabel 3. Analisis SWOT Mataair Asin di Desa Kaliduren

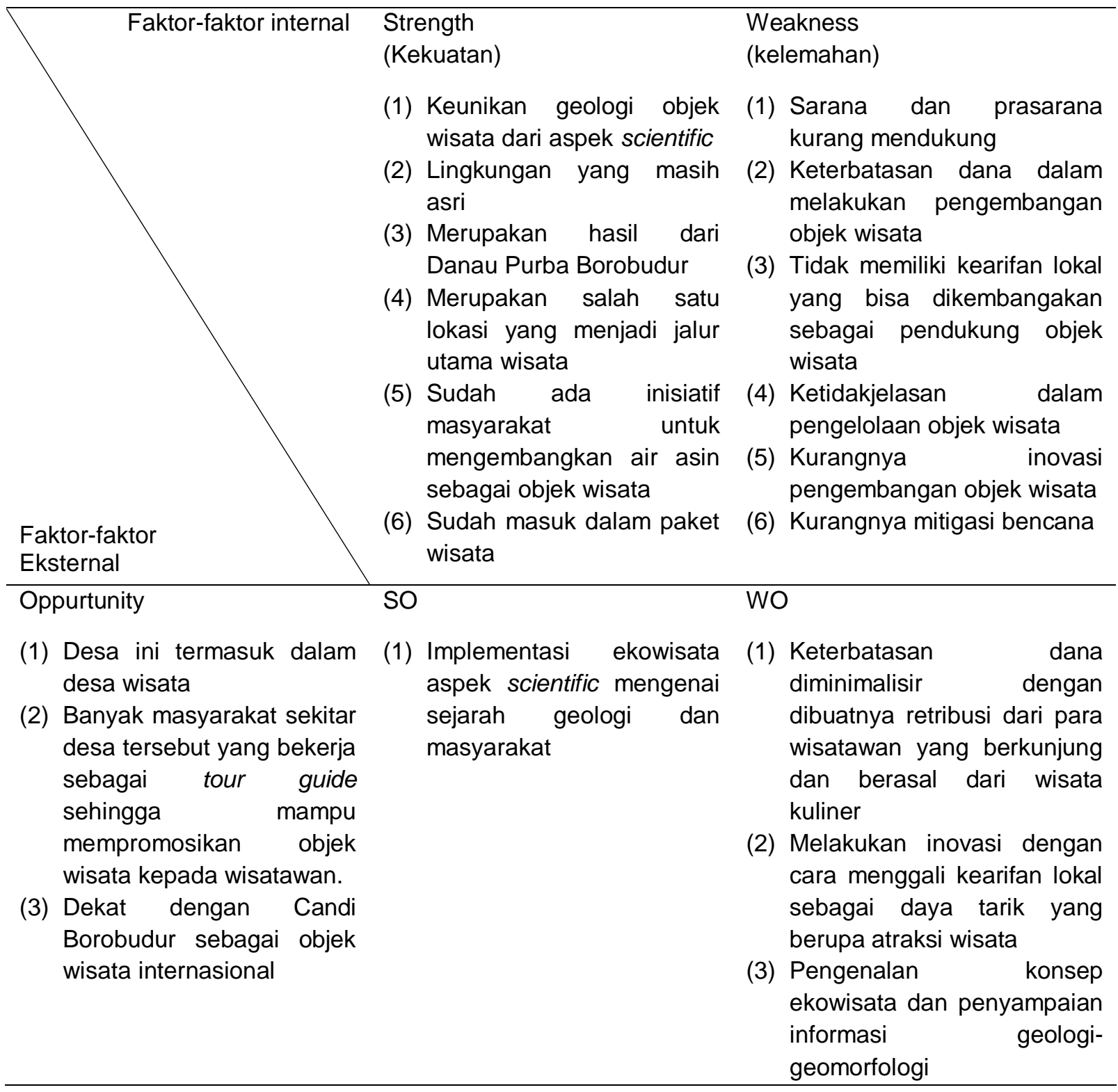

Lokasi pertemuan antara Sungai Progo dengan Sungai Elo cukup menarik untuk direkomendasikan sebagai objek ekowisata minat khusus. Daya tarik utama dari lokasi ini adalah fenomena alam berupa pertemuan dua sungai. Disamping itu dari segi aesthetic, wilayah ini juga masih bernuansa alami sehingga menambah daya tarik bagi wisatawan. Keberadaan pertemuan dua sungai yaitu Sungai Elo dan Sungai Progo ini juga terkait dengan Danau Purba Borobudur di masa lalu. Walaupun mempunyai nilai scietific yang tinggi untuk 
ekowisata namun lokasi ini juga memiliki terjal. Oleh karena itu perlu perencanaan desain kelemahan yaitu aksesibilitas yang kurang tata ruang yang baik dengan memperhatikan memadai. Secara fisik objek ini juga cukup standar keamanan untuk mengoptimalkan berbahaya dengan arus yang deras serta lereng potensi yang ada di lokasi ini.

Tabel 4. Analisis SWOT lokasi Pertemuan Sungai Progo dan Sungai Elo

\begin{tabular}{|c|c|c|}
\hline $\begin{array}{l}\text { Faktor-faktor } \\
\text { Eksternal }\end{array}$ & $\begin{array}{l}\text { Strength } \\
\quad \text { (Kekuatan) } \\
\text { (1) Keunikan geologis dan } \\
\text { geomorfologis } \\
\text { (2) Sudah ada inisiatif dari } \\
\text { masyarakat sekitar } \\
\text { (3) Lingkungan yang masih } \\
\text { asri }\end{array}$ & $\begin{array}{l}\text { Weakness } \\
\text { (kelemahan) } \\
\text { (1) Aksesibilitas yang sulit } \\
\text { untuk dijangkau } \\
\text { (2) Belum masuk dalam paket } \\
\text { wisata }\end{array}$ \\
\hline Oppurtunity & SO & WO \\
\hline $\begin{array}{l}\text { (1) Berpotensi } \\
\text { ekowisata berbasis edukasi } \\
\text { (2) Menyuguhkan suasana } \\
\text { yang mendukung } \\
\text { (3) Dekat dengan Candi } \\
\text { Borobudur }\end{array}$ & $\begin{array}{l}\text { (1) Implementasi } \\
\text { aspek } \\
\text { mengenisata } \\
\text { geologi dan geomorfologi } \\
\text { (2) Dapat berkembang } \\
\text { menjadi objek wisata } \\
\text { baru dengan konsep } \\
\text { petualangan }\end{array}$ & $\begin{array}{l}\text { (1) Mengembangkan wisata } \\
\text { yang dapat memacu } \\
\text { adrenalin }\end{array}$ \\
\hline $\begin{array}{l}\text { Threat } \\
\text { (1) Terjadinya banjir } \\
\text { (2) Adanya binatang } \\
\text { (ular) }\end{array}$ & $\begin{array}{l}\text { ST } \\
\text { (1) Membuat jalur evakuasi } \\
\text { (2) Membuat jalan yang } \\
\text { berasal dari bahan } \\
\text { ramah lingkungan untuk } \\
\text { menghindari terjadinya } \\
\text { bahaya binatang buas }\end{array}$ & $\begin{array}{l}\text { WT } \\
\text { (1) Masyarakat melakukan } \\
\text { kerjasama dengan pihak } \\
\text { travel maupun hotel agar } \\
\text { objek masuk dalam paket } \\
\text { wisata } \\
\text { (2) Memberikan informasi } \\
\text { ataupun sosialisasi } \\
\text { mengenai ancaman di objek } \\
\text { wisata }\end{array}$ \\
\hline
\end{tabular}

Sumur air asin di Dusun Ngentak juga memiliki potensi yang direkomedasikan sebagai lokasi ekowisata. Hal ini karena sumur ini juga menunjukkan jejak evolusi dari Danau Borobudur Purba. Letak sumur asin ini tidak jauh dari permukiman warga. Bahkan Sumur Asin ini sudah dikelola dengan membuat semacam bendungan untuk menampung air yang terus mengalir dari tanah. Dalam kaitannya dengan pengembangan wisata, sebenarnya sudah ada insiatif dari masyarakat setempat untuk menjadikan tempat ini sebagai tempat wisata. Pengembangan yang telah dilakukan oleh masyarakat ini dapat diperluas dengan desain ekowisata dengan adanya potensi nilai scientific yang tinggi dari keberadaan sumur air asin ini.
Tabel 5 menunjukkan analisis SWOT untuk lokasi sumur air asin.

Hasil analisis SWOT yang telah dilakukan untuk setiap lokasi selanjutnya dapat digunakan untuk menyusun desain pegembangan ekowisata. Desain pengembangan ekowisata dibuat secara tematik sesuai dengan karakteristik objek serta kekuatan, kelemahan, peluang, dan ancaman yang dimiliki masing-masing objek sebagaimana telah dianalisis melalui SWOT. Pengembangan ekowisata juga perlu disertai dengan pengembangan parasarana dan sarana pendukung. Desain pengembangan ekowisata di sekitar Candi Borobudur yang direkomendasikan berdasarkan hasil analisis ditunjukkan oleh Gambar 4 dan Tabel 6. 
Tabel 5. Analisis SWOT Sumur Asin di Desa Ngentak

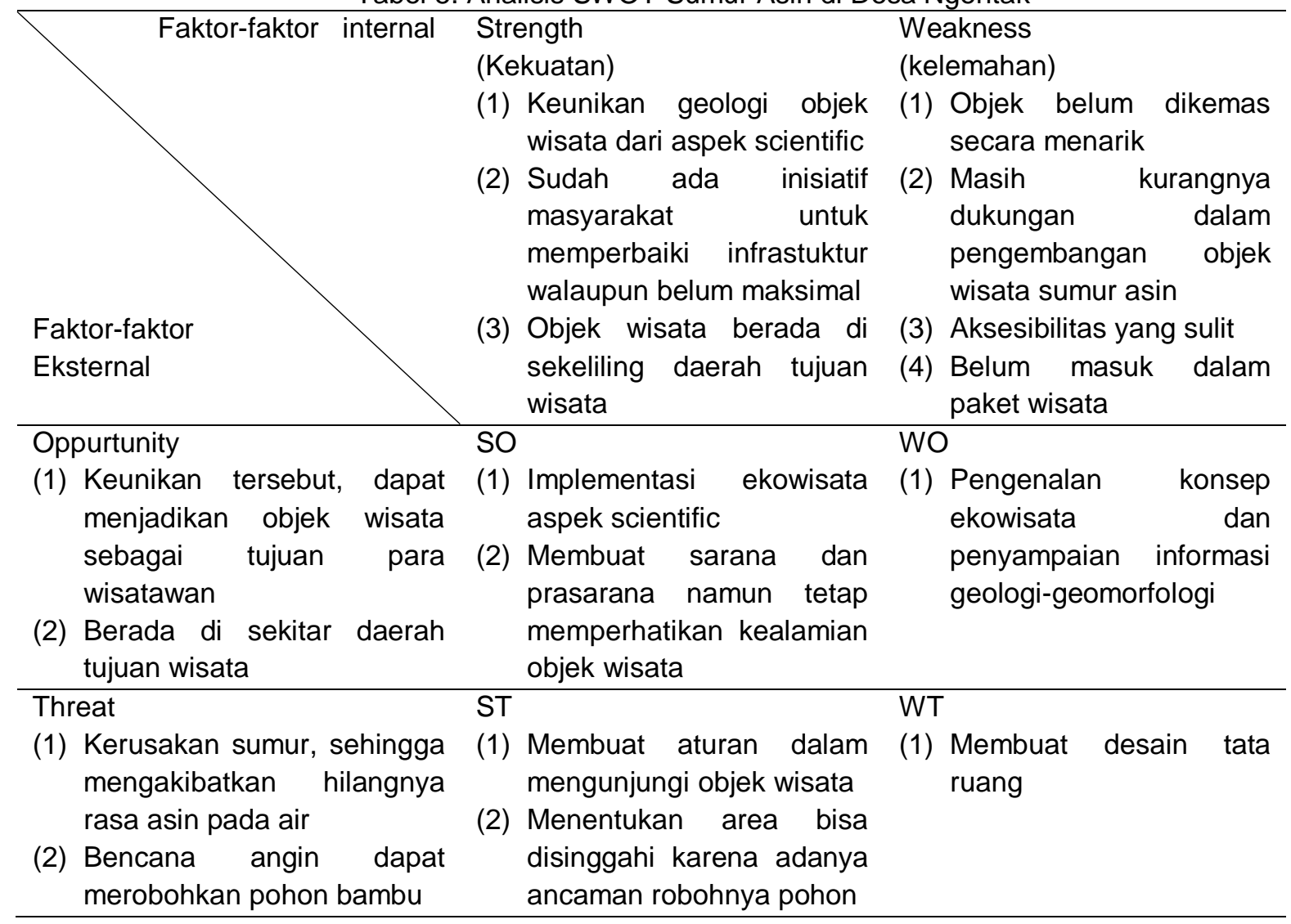

\section{DENAH TATA RUANG PENGEMBANGAN EKOWISATA JEJAK DANAU PURBA BOROBUDUR}

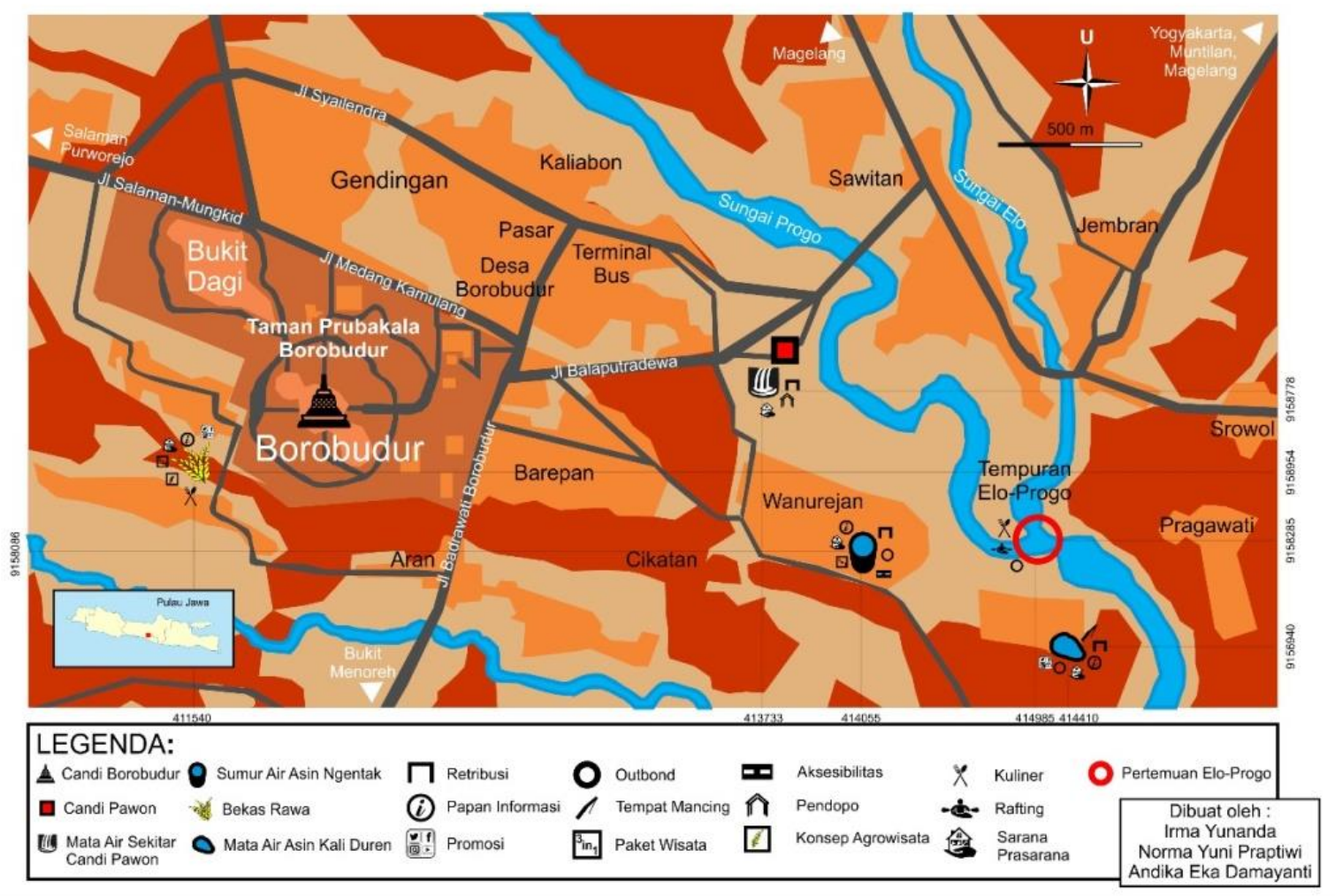

Gambar 4. Denah Pengembangan Ekowisata di Sekitar Candi Borobudur 
Tabel 2 Desain Pengembangan Ekowisata

\begin{tabular}{|c|c|}
\hline Objek Wisata & Desain Pengembangan Ekowisata \\
\hline \multirow[t]{6}{*}{ Mataair asin di Kaliduren } & $\begin{array}{l}\text { Membuat tempat retribusi bertujuan untuk sebagai income } \\
\text { masyarakat sekitar }\end{array}$ \\
\hline & $\begin{array}{l}\text { Membuat papan pengetahuan mengenai asal mataair asin } \\
\text { secara fisik }\end{array}$ \\
\hline & $\begin{array}{l}\text { Membuat sarana dan prasarana berupa fasilitas umum } \\
\text { (kamar mandi, tempat berteduh, kuliner wisata) }\end{array}$ \\
\hline & Mengembangkan wisata berbasis outbond \\
\hline & Menggencarkan promosi ke media sosial \\
\hline & Menjadikan sebagai tempat pemancingan \\
\hline \multirow[t]{7}{*}{$\begin{array}{l}\text { Bekas Rawa di antara Ds. } \\
\text { Bumisegoro dan Ds. Sabrangrawa }\end{array}$} & $\begin{array}{l}\text { Membuat papan pengetahuan mengenai keterdapatan rawa } \\
\text { pada jaman dahulu dengan toponim dan aspek geologi }\end{array}$ \\
\hline & $\begin{array}{l}\text { Membuat sarana dan prasarana berupa fasilitas umum } \\
\text { (tempat berteduh) }\end{array}$ \\
\hline & Menjadikan objek ini ke dalam paket wisata \\
\hline & Menyediakan konsep agrowisata \\
\hline & Membuat wisata kuliner \\
\hline & Menjadikan objek ini ke dalam paket wisata \\
\hline & Menggencarkan promosi media sosial \\
\hline \multirow[t]{6}{*}{ Sumur Asin di Desa Ngentak } & Mengembangkan wisata berbasis outbond \\
\hline & $\begin{array}{l}\text { Membuat retribusi bertujuan untuk sebagai income } \\
\text { masyarakat sekitar }\end{array}$ \\
\hline & Mengembangkan fasilitas umum (tempat berteduh) \\
\hline & $\begin{array}{l}\text { Membuat papan pengetahuan dalam aspek geologi dan } \\
\text { geomorfologi }\end{array}$ \\
\hline & Memperbaiki aksesibilitas untuk menuju objek \\
\hline & Menjadikan objek ini ke dalam paket wisata \\
\hline \multirow[t]{3}{*}{$\begin{array}{l}\text { Beberapa mataair di sekitar Candi } \\
\text { Pawon }\end{array}$} & $\begin{array}{l}\text { Membuat retribusi bertujuan untuk sebagai income } \\
\text { masyarakat sekitar }\end{array}$ \\
\hline & $\begin{array}{l}\text { Membuat pendopo sesuai dengan aturan pembangunan } \\
\text { sebagai tempat berteduh }\end{array}$ \\
\hline & $\begin{array}{l}\text { Membuat kamar mandi di sekitar mataair dengan } \\
\text { menggunakan bambu }\end{array}$ \\
\hline \multirow[t]{3}{*}{ Pertemuan Sungai Elo dan Progo } & $\begin{array}{l}\text { Membuat wisata kuliner dengan daya tarik gemercik air } \\
\text { sungai dengan mempertimbangkan aturan pendirian } \\
\text { bangunan }\end{array}$ \\
\hline & Membuat wisata rafting \\
\hline & Mengembangkan wisata berbasis outbond \\
\hline
\end{tabular}

\section{Simpulan}

Kawasan Borobudur identik dengan keberadaan Candi Borobudur yang menjadi destinasi wisata internasional. Namun demikian tidak hanya terbatas pada itu saja, kawasan ini sebenarnya juga mempunyai potensi lain untuk dikembangkan sebagai tujuan wisata. Ekowisata yang bernilai scientific dengan mengangkat keunikan geologis dan geomorfologis di wilayah ini sangat memungkinkan untuk dikembangkan. Beberapa objek memiliki nilai scientific dan philosophical yang ditunjuang dengan keindahan panorama alam sebagai daya tarik dari aspek aesthetic. Untuk mengembangkan ekowisata di wilayah ini dapat disusun desain tata ruang dengan memperhatikan aspek kekuatan, kelemahan, peluang, dan ancaman. Melalui pengembangan ekowisata ini diharapkan nilainilai scientific dan philosophical yang terdapat di wilayah ini dapat dikelola secara optimal. Disisi lain dengan adanya ekowisata diharapkan dapat menjadi pendukung pariwisata Candi Borobudur. 


\section{Ucapan terima kasih}

Penelitian ini dilaksanakan melalui Program Kreativitas Mahasiswa Penelitian Sosial Humaniora (PKM-PSH) Tahun 2018. Penulis mengucapkan terimakasih kepada berbagai pihak yang telah membantu dalam penelitian ini. Ucapan terima kasih secara khusus disampaikan kepada Bapak Drs. Nurhadi M.Si selaku pembimbing dan Bapak Arif Ashari M.Sc yang telah memberikan banyak masukan dan referensi dalam pelaksanaan penelitian ini. Penulis juga mengucapkan banyak terimakasih kepada Kemenristekdikti yang telah memberikan kesempatan dan pembiayaan bagi penelitian ini melalui Program PKM-PSH Tahun 2018.

\section{Referensi}

Baiquni, M. (2001). Ekowisata Kawasan Karst, Belajar dari Guilin China untuk Pengembangan Wisata di Wonogiri. dalam Haryono, E. dan Adji, T.N. (2004) Pengantar Geomorfologi dan Hidrologi Karst. Yogyakarta: Fakultas Geografi Universitas Gadjah Mada.

Bemmelen, R.W.Van. (1949). The Geology of Indonesia, Vol IA General Geology of Indonesia and Adjacent Archipelago. The Haque: Government Printing Office.

Ida. 2016. Desa Wisata Candirejo. Retrieved July 15, 2018, from http://goborobudur.com 12016/01/05/desa-wisata-candirejo/

Masruri, M.S. (2017). Analisis Kondisi Geologis dan Geomorfologis Wilayah Sekitar Escarpment Baturagung untuk Pengembangan Ekowisata. Geomedia 15 (2), 165-181

Murwanto, H. (2015). Penelusuran Jejak Lingkungan Danau Purba di Sekitar Candi
Borobudur dengan Pendekatan Paleogeomorfologi, Ringkasan Disertasi. Yogyakarta: Program Pascasarjana, Fakultas Geografi, Universitas Gadjah Mada Murwanto, H., \& Purwoaminta, A. (2015). Rekonstruksi Danau Purba Borobudur dengan Pendekatan Spasiotemporal. Limnotek, 22(2), 106-117.

Murwanto, H., Purwoarminta, A., \& Siregar, D. A. (2014). Pengaruh tektonik dan longsor lahan terhadap perubahan bentuklahan di bagian selatan Danau Purba Borobudur. Jurnal Lingkungan Dan Bencana Geologi, 5(2), 143-158.

Nuraini, F. dan Pramono, H. (2013) Kajian Krakteristik dan Potensi Kawasan karst untuk Pengembangan Ekowisata di Kecamatan Ponjong Kabupaten Gunungkidul. Geomedia 11 (1), 109-127

Parwito. 2013. Pendapatan Candi Borobudur Melejit, Warga Sekitar Masih Sengsara. Retrieved November 7, 2017 from https://www.google.com.id/amp/m.merdeka. com/amp/peristiwa/pendapatan-candiborobudur-melejit-warga-sekitar-masihsengsara.html/.

Priherdityo, E. (2017). Candi Borobudur Dikunjungi 3,7 Juta Wisatawan Selama 2016. Retrieved November 7, 2017 from https://m.cnnindonesia.com.

Verstappen, H. T. (2013). Garis Besar Geomorfologi Indonesia. (Suratman, Ed.) (1st ed.). Yogyakarta: Gadjah Mada University Press. 